1352-2310(95)00456-4

\title{
NITROGEN MOBILIZATION IN THE UNITED STATES OF AMERICA AND THE PEOPLE'S REPUBLIC OF CHINA
}

\author{
JAMES N. GALLOWAY,* ZHAO DIANWU, $\dagger$ VIVIAN E. THOMSON, $\ddagger$ \\ and LISA H. CHANG*
}

*Department of Environmental Sciences, University of Virginia, Charlottesville, VA 22903, U.S.A.; †Research Center for Eco-Environmental Sciences, P.O. Box 2871, Beijing 100085, People's Republic of China; and $\ddagger$ Department of Government and Foreign Affairs, University of Virginia, Charlottesville, VA 22903, U.S.A.

(First received 1 February 1995 and in final form 26 October 1995)

\begin{abstract}
Through fossil-fuel combustion, commercial fertilizer production, and legume and rice cultivation, humans are mobilizing nitrogen $(\mathrm{N})$ at scales that exceed natural terrestrial rates. Globally, $\approx 140 \mathrm{Tg}$ of reactive $\mathrm{N}$ are mobilized each year; activities in the People's Republic of China (China) and the United States account for approximately $30 \%$ of this reactive $\mathrm{N}$. This paper compares $\mathrm{N}$ mobilization rates and nitrogen oxides $\left(\mathrm{NO}_{x}\right)$ and ammonia $\left(\mathrm{NH}_{3}\right)$ atmospheric emission rates for China and the United States over the last few decades and projects the rates to the year 2020. We have estimated that the United States and China currently mobilize about 20 and $25 \mathrm{Tg} \mathrm{N} \mathrm{yr}^{-1}$, respectively. In the United States, commercialfertilizer use accounts for about $50 \%$ of the annual total; in China, it accounts for about $80 \%$. $\mathrm{N}$ emissions to the United States atmosphere are dominated by $\mathrm{NO}_{x}$. China's $\mathrm{N}$ emissions are dominated by $\mathrm{NH}_{3}$ from fertilizer use and domestic animal waste. If recent trends continue, we have projected that by 2020 $\mathrm{N}$ mobilization in the United States will differ little from current levels although $\mathbf{N}$ mobilization in China will increase significantly because of increased fertilizer use and fossil-fuel combustion.
\end{abstract}

Key word index: Ammonia, nitrogen oxides, nitrous oxide, fertilizer, fossil-fuel combustion, agriculture, biogeochemical cycles.

\section{INTRODUCTION}

Nitrogen ( $\mathrm{N}$ ) has an important role in atmospheric photochemistry, organismal metabolism, and ecosystem productivity. It is also in short supply. Most $\mathrm{N}$ on the Earth's surface is unreactive $\left(\mathbf{N}_{2}\right)$, thus a source of energy is required to convert unreactive $\mathrm{N}_{2}$ to reactive $\mathrm{N}\left(\mathrm{N}_{\mathrm{R}}\right)$-i.e. in a form in which it can affect a biogeochemical. process $\left(\mathbf{N}_{\mathbf{R}}=\mathbf{N H}_{x}, \quad \mathbf{N}_{x} \mathrm{O}_{y}\right.$ and organic $\mathrm{N}$, where $\mathrm{NH}_{x}=\mathrm{NH}_{3}+\mathrm{NH}_{4}^{+}$aerosol and where $\mathrm{N}_{x} \mathrm{O}_{y}$ is any combination of $\mathbf{N}$ and $\mathrm{O}$ ). The most important natural sources of $\mathrm{N}$ are biological $\mathrm{N}$ fixation and lightning. Globally, biological $\mathbf{N}$ fixation exceecs lightning as a source of $\mathbf{N}_{R}$ by two orders of magnitude (Galloway et al., 1995).

Significant human intervention in the $\mathrm{N}$ cycle began with the use of fossil fuels and accelerated dramatically with the rising fuel consumption and with increased $\mathrm{N}$ fertilizer application. Before the industrial age, $\mathrm{N}_{\mathrm{R}}$ produced by human activities was minimal compared to that produced by biological $\mathrm{N}$ fixation. Today, $\mathrm{N}_{\mathrm{R}}$ produced by human activities is approximately equal to that produced by terrestrial biological $\mathrm{N}$ fixation because of fossil-fuel combustion, commercial fertilizer application, and legumes and rice cultivation (Ayres et al., 1994; Galloway et al., 1994; Galloway et al., 1995).

Once formed, $\mathbf{N}_{\mathbf{R}}$ can be widely distributed. It can be emitted to the atmosphere and then deposited to downwind ecosystems. Reduced $N_{R}$ applied as fertilizer can be (1) lost as nitrate $\left(\mathrm{NO}_{3}^{-}\right)$via hydrologic transport, (2) volatilized as ammonia $\left(\mathrm{NH}_{3}\right)$, or (3) transformed by microbial processes to nitrous oxide $\left(\mathrm{N}_{2} \mathrm{O}\right)$ and nitric oxide (NO). Except for $\mathrm{N}_{2} \mathrm{O}$, any form of $N_{R}$ may be changed into any other form. Thus human intervention at any point in the $\mathrm{N}$ cycle can alter the distribution and abundance of any $\mathrm{N}$ species, each of which has a unique effect on biogeochemical processes.

The food production increases from applied fertilizer that have brought such enormous benefits to humankind have also caused $N_{R}$ to be liberated and have impacted ecosystems and humans alike. For example, nitrogen oxides $\left(\mathrm{NO}_{x}\right)$ may react in the atmosphere to form ground-level ozone $\left(\mathrm{O}_{3}\right)$, which can adversely affect the human respiratory system and damage crops and natural vegetation (Heck et al., 1986; Chameides et al., 1994). Nitrogen oxides may also react in the atmosphere to form nitric acid or nitrate ion, either of which can contribute to acid deposition (Galloway and Likens, 1981). Excess $\mathrm{N}$ in 
aquatic ecosystems can speed eutrophication (Nixon, 1995). Excess $N$ inputs may cause " $N$ saturation", which can change terrestrial and aquatic ecosystems in many ways (Aber et al., 1989).

Economic development might cause $\mathrm{N}_{R}$ to increase but is this relationship inevitable? Will patterns in $\mathrm{N}_{R}$ creation and emissions differ according to a country's individual development pattern? We are beginning to investigate these questions for the United States and the People's Republic of China (China). We selected these countries because we expected the $N_{R}$ released in both countries to contribute heavily to global levels but for different reasons. The United States displays a high gross domestic product (GDP) per capita and relatively low population growth whereas China has a low GDP per capita, a rapidly growing economy, and a large and expanding population.

We posed the following questions: (1) How do historical rates of $N_{R}$ mobilization and atmospheric $\mathrm{N}$ emissions compare in the United States and China? and (2) What might happen to $\mathrm{N}_{\mathrm{R}}$ mobilization and $\mathrm{N}$ atmospheric emissions if recent trends persist into the foreseeable future? We used 1950 to 1990 as our historical base and then made projections to 2020 . These extrapolations demonstrate what might happen if present trends continue.

Thomson and Galloway (1994) used the data presented in this paper to examine the relationship between economic growth and $\mathrm{N}$ mobilization in the United States and China. They analyze whether the development paths in these two countries conform to theoretical expectations about the connection between growth and pollution and nest these conclusions within a discussion of sustainable development.

\section{DATA}

\section{$N_{\mathrm{R}}$ creation}

Combustion. EPA (1994) gives emission estimates as well as detailed descriptions of the methodologies used for determining emissions in the United States and the associated analytical assumptions in its most recent report on emission trends (S. Nizich, Office of Air Quality Planning and Standards, EPA, personal communication, 1994). We also used EPA's emission projections for 2000, 2005, and 2010 (S. Nizich, Office of Air Quality Planning and Standards, EPA, personal communication, 1994) and extrapolated those for 2115 and 2020 by applying projected rates of population growth from Urban and Trueblood (1990). Emission projections are, at best, educated guesses and, in this case, depend on assumptions regarding (1) future economic growth and (2) whether currently expected industrial and mobile source controls will actually materialize.

We calculated $\mathrm{NO}_{x}$ emissions in China for primaryenergy and biomass (wood and crop residue) consumption for the period 1952 to 1989 and extrapolated to 2020 . Because the $\mathrm{NO}_{x}$ emission factors vary by fuel type and economic sector and because we lacked detailed information on energy used before 1980 , we used a two-stage process to calculate $\mathrm{NO}_{x}$ emissions from 1952 to 1990 . The first stage used detailed information on fuel use by economic sector for 1980-1989; the second stage used general information on fuel use for 1952-1979. For 1980-1989, we used information on coal and petroleum consumption by sector from Sinton et al. (1993) and emission factors, converted to kilograms of nitrogen per metric ton of coal equivalent $\left(\mathrm{kg} \mathrm{N}_{\mathrm{tce}}^{-1}\right)$, from the European and Chinese sources in Table 1. Using an emission-factor range from NEPA [Chinese National Environmental Protection Agency, unpublished internal report (in Chinese), 1994] for coal combustion in industrial boilers (Table 1), we tabulated the $\mathrm{NO}_{x}$ emissions and obtained minimum and maximum values. For the period 1952-1979, we estimated $\mathrm{NO}_{x}$ emissions from primary-energy consumption by combining total solid- and liquid-fuel consumed (Sinton $e t$ al., 1993) with coal-emission factors for industrial boilers and the average emission factor for diesel fuel (Table 1). To calculate $\mathrm{NO}_{x}$ emissions from biomass,

Table $1 . \mathrm{NO}_{x}$ emission factors by fuel and combustion type used for China

\begin{tabular}{|c|c|c|c|}
\hline & \multicolumn{2}{|c|}{ Emission factors } & \multirow[b]{2}{*}{ References } \\
\hline & $\left(\mathrm{kg} \mathrm{NO}_{2} \operatorname{ton}^{-1}\right)$ & $\left(\mathrm{kgNtce}{ }^{-1}\right)$ & \\
\hline \multicolumn{4}{|l|}{ Coal } \\
\hline Power plant & 4.1 & 1.75 & Shen, unpublished report, $1985^{\mathrm{a}}$ \\
\hline Residential & 0.58 & 0.247 & Shen, unpublished report $1985^{\mathrm{a}}$ \\
\hline Industrial boiler & $1.1-5.2$ & $0.47-2.22$ & NEPA, $1994^{\mathrm{b}}$ \\
\hline Coke & 5.8 & 2.47 & Pacyna et al., 1991 \\
\hline Crude and fuel oil & 8 & 1.70 & Semb and Amble, 1981 \\
\hline Gasoline & 42 & 8.69 & Pacyna et al., 1991 \\
\hline Diesel (light truck) & 15 & 3.12 & Pacyna et al., 1991 \\
\hline
\end{tabular}


we used fuel-consumption data for 1979 and 1987 $\left[120 \times 10^{6}\right.$ tce and $134 \times 10^{6}$ tce, respectively (Sinton et al., 1993) ] and an emission factor of $1.34 \mathrm{~kg} \mathrm{~N}$ tce $^{-1}$ (Table 1). For other years we scaled biomass consumption to population and used the same emission factor. We did not tabulate $\mathrm{NO}_{x}$ emissions from coal gas and natural gas because at this time they are not extensively used in China.

There are several projections for Chinese fuel use in the future. The International Energy Agency of the Organization for Economic Cooperation and Development (IEA, 199.2) estimates that future fuel consumption in China will grow annually at about $3.2 \%$ and $3.6 \%$ for coal and oil, respectively, through 2005 . The Chinese State Planning Commission (1993) predicts that total energy use will grow at an annual rate of $6-7.5 \%$ to 2010 . Arndt and Carmichael (1995) estimate that energy use will increase about $3.5-4.5 \% \mathrm{yr}^{-1}$ (depending on the degree of energyefficient operations developed) from 1990 to 2020 . For this paper, we have used the IEA projections of energy use to 2020. In addition, we employed the current $\mathrm{NO}_{x}$ emission factors in Table 1 to calculate future $\mathrm{NO}_{x}$ emission.

Fertilizer application. The United States fertilizer data and the $\mathrm{N}$ content of nitrogenous fertilizer were obtained from J. T. Berry, Tennessee Valley Authority, National Fertilizer and Environmental Research Center in Muscle Shoals, Alabama, in 1993. The most important $\mathrm{N}$ fertiliz'ers used in the United States in the late 1980 s were anhydrous $\mathrm{NH}_{3}, \mathrm{~N}-\mathrm{P}-\mathrm{K}$ mixtures, urea, and N solutions. Constant and Sheldrick (1992) project only small increases $\left(0.21 \% \mathrm{yr}^{-1}\right)$ in fertilizer use from 1989-2001; we extended their projections to 2020.

For China, we obtained statistics for total $\mathrm{N}$ fertilizer from United Nations documents that provided information for 1963-1989 (UN Statistical Yearbooks, 1971, 1972, 1973, 1974, 1975, 1976, 1977, 1978, 1979-1980, 1981, 1982, 1983-1984, 1985-1986, 1987, 1988-1989). We obtained information on fertilizer type from Smil (1993), who categorized fertilizer used between 1970 and 1990 as urea, ammonium bicarbonate, and "others." In 1970, approximately equal amounts of urea, ammonium bicarbonate, and "others" were applied. By 1990, about half of the fertilizer used was ammonium bicarbonate and most of the rest was urea. Our projections are based on the Constant and Sheldrick (1992) estimate that fertilizer use in East Asia will grow by $2.73 \%$ annually until $2000 / 2001$. We extended that rate to 2020 and assumed that any additional fertilizer would be urea or ammonium bicarbonate.

Legume and rice cultivation. Legume cultivation increases symbiotic $\mathbf{N}$ fixation by providing sites for $\mathrm{N}$-fixing bacteria. Rice cultivation provides an anaerobic environment in which $\mathrm{N}$-fixing organisms can thrive. To estimate the amount of $\mathbf{N}$ fixed by legume and rice cultivation, we used information on the area cultivated and on the $\mathrm{N}$-fixation rate. The total
Table 2. 1980 and 1990 legume and rice cultivation and $\mathrm{N}$ fixation in the U.S. and China

\begin{tabular}{lrrrrr}
\hline & \multicolumn{2}{c}{1980} & & \multicolumn{2}{c}{1990} \\
\cline { 2 - 3 } \cline { 5 - 6 } \cline { 5 - 6 } & U.S. & China & & U.S. & China \\
\hline Land under cultivation, & ha $10^{6}$ & & & \\
Pulses & 0.9 & 5.4 & & 1.0 & 4.4 \\
Soybeans & 27.6 & 7.5 & & 22.9 & 7.6 \\
Groundnuts & 0.6 & 2.4 & & 0.7 & 2.9 \\
Rice & 1.3 & 34.3 & & 1.1 & 33.5 \\
$N$ fixation, $T g N$ & & & & \\
Minimum & 2.1 & 2.3 & & 1.8 & 2.3 \\
Maximum & 4.1 & 3.4 & 3.5 & 3.3 \\
\hline
\end{tabular}

Source: Land data from the Food and Agriculture Organization of the United Nations (FAO, 1993).

$\mathrm{N}$-fixation rate was calculated by multiplying the land area by the fixation rate per hectare.

For cultivated areas in the United States and China, we used data for 1979-1981 and 1990 (FAO, 1993) for pulses (e.g. lentils), soybeans, groundnuts (peanuts), and rice. We were unable to find equivalent data for vetch, clover, or alfalfa. For legumes, Burns and Hardy (1975) estimate that an "average" N-fixation rate by legumes is $140 \mathrm{~kg} \mathrm{Nha}^{-1}$. LaRue and Patterson (1981) state that this value may be too large by a factor of two. In their review, they present ranges of $9-290 \mathrm{~kg} \mathrm{~N} \mathrm{ha}^{-1}$ for forage crops (e.g. alfalfa), $14.7-263 \mathrm{~kg} \mathrm{Nha}^{-1}$ (average $75 \mathrm{~kg} \mathrm{~N} \mathrm{ha}^{-1}$ ) for soybeans in North America, and $10-222 \mathrm{~kg} \mathrm{Nha}^{-1}$ for pulse crops. Their estimates of the $\mathrm{N}$ fixed by legume crops vary. Keyser and $\mathrm{Li} \mathrm{(1992)}$ review the range of biological $\mathrm{N}$ fixation in soybeans from nine investigations. The range of the median biological $\mathrm{N}$-fixation rates from those studies is $72-201 \mathrm{~kg} \mathrm{~N}^{-1}$. Based on the above, Galloway et al. (1995) estimate a range of fixation rates of $70-140 \mathrm{~kg} \mathrm{~N} \mathrm{ha}^{-1}$ for legumes. Burns and Hardy (1975) estimate a fixation rate for rice on the order of $30 \mathrm{~kg} \mathrm{Nha}^{-1}$. To calculate $\mathrm{N}$ fixation by legumes, we multiplied Galloway et al.'s fixation rate of $70-140 \mathrm{~kg} \mathrm{ha}^{-1}$ for legumes and the Burns and Hardy's fixation rate for rice by the Food and Agriculture Organization's (FAO, 1993) data on cultivated areas for soybeans, groundnuts, pulses, and rice (Table 2). For fixation caused by cultivation in 2020 , since the rate appears to be relatively constant, we assumed the rate would be equal to current values. There are several reasons why this might be a poor assumption, including changes in cultivation area, crop mix, and agricultural practices.

\section{$N_{\mathrm{R}}$ emission}

Anthropogenic $N_{R}$ is emitted to the atmosphere mostly as $\mathrm{NO}_{x}$ from combustion, as $\mathrm{NH}_{3}$ from fertilizer application, as $\mathrm{NH}_{3}$ from animal wastes, and as $\mathrm{N}_{2} \mathrm{O}$ and NO from microbial transformation of fertilizer $\mathrm{N}$. We have already presented our calculation method for $\mathrm{NO}_{x}$ produced by combustion. For $\mathrm{NH}_{3}$ 
Table 3. Fertilizer emission factors, percentage of $\mathrm{N}$ applied

\begin{tabular}{lcccl}
\hline Urea & $\mathrm{NH}_{4} \mathrm{NO}_{3}$ & $\left(\mathrm{NH}_{4}\right)_{2} \mathrm{SO}_{4}$ & Other $\mathrm{N}$ fertilizers & \multicolumn{1}{c}{ Reference } \\
\hline 20.0 & 2.5 & 10.0 & 3.0 & Schlesinger and Hartley, 1992 \\
10.0 & - & - & $5.0^{\mathrm{b}}$ & Zhao and Wang, 1994 \\
15 & 2 & 8 & $1-4$ & Battye et al., 1994 \\
\hline
\end{tabular}

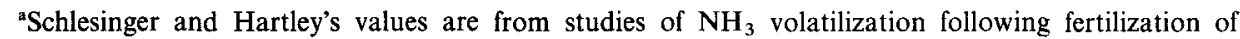
agricultural fields, pastures, and forests.

'Zhao and Wang grouped all non-urea chemical $\mathrm{N}$ fertilizers together and assigned them the same value of $5.0 \%$. Their estimates are based on studies of $\mathrm{N}$ loss from chemical fertilizer applications in European countries.

we estimated emissions only from animal waste and fertilizer use, which contribute up to $90 \%$ of anthropogenic $\mathrm{NH}_{3}$ emissions in the United States (Battye et al., 1994). In China, other anthropogenic activities (e.g. biomass burning, fertilizer manufacture, sewage treatment) may be more important $\mathrm{NH}_{3}$ sources than they are in the United States.

Two parameters are required to estimate $\mathrm{NH}_{3}$ emissions from fertilizer-fertilizer amount and an emission factor. The latter depends on soil texture, fertilizer application temperature, timing and method, animal-housing conditions, waste-storage method, and animal diet. In the previous section we have presented our data sources for fertilizer use from 1950 to 2020 and information on types of fertilizer. Several studies have estimated emission factors for $\mathrm{NH}_{3}$ volatilization from fertilizers (see Table 3). For the United States, we used the estimates of Battye et al. (1994). For their category "other $\mathrm{N}$ fertilizer", we used a median emission factor of $2.5 \%$ for the United States. Most fertilizer used in China is urea or ammonium bicarbonate (Smil, 1993). Although the studies in Table 3 present urea emission factors, there are none for ammonium bicarbonate. Smil (1995) states that the emission factor exceeds $20 \%$; Wang (1974) says that at moisture levels of $\approx 5 \%$, all of the ammonium bicarbonate is lost to the atmosphere in $12 \mathrm{~d}$, before application. In the absence of an ammonium bicarbonate emission factor, we used a range for the urea emission factor of $10-20 \%$. Because most applied fertilizer is either urea or ammonium bicarbonate, we applied this range to total fertilizer $\mathrm{N}$ for the entire period of record and for our projection to 2020 . It should be stressed that, given the instability of ammonium bicarbonate, it is likely that this emissionfactor range-and the resulting $\mathrm{NH}_{3}$ emission-is a significant underestimate.

Estimating $\mathrm{NH}_{3}$ emissions from animal waste requires animal population data and an emission factor per animal. Our primary data sources for animal populations in both the United States and China were FAO (FAO, 1958, 1963, 1968, 1971, 1973, 1976, 1979, 1982, 1988, 1990) and the United Nations statistical yearbooks (UN, 1988-1989). United States poultry data were obtained from the United States Department of Agriculture's statistical yearbooks for 1951-1992 (USDA, 1951-1992).
Broiler chickens, chickens raised solely for consumption, were not included in the overall poultry data. Annual production of broilers was converted to a standing-stock value by dividing the production value by an approximate value for the number of flocks raised per year (4.0 for 1950-1959, 4.4 for 1960-1969, 5.0 for 1970-1979, 5.1 for 1980-1989, and 5.2 after 1989; William Roenigk, National Broiler Council, personal communication, 1995). Because of their limited numbers, we have not included ducks or turkeys in our estimates. For the United States, the Department of Agriculture has projected changes in meat production to 2005 (USDA, 1995). They project slightly decreased beef, pork, and lamb production and increased poultry production (about $1-2 \% \mathrm{yr}^{-1}$ ). We extended the 2005 projections to 2020 . For China, we assumed animal populations would increase between 1990 and 2020 at the same rate as human populations; in other words, we assumed that the per capita animal population would remain constant. This assumption probably resulted in an underestimate. We know that the per capita consumption of meat has been increasing in China (Smil, 1995) and it is likely to continue to increase. However, changes in animal populations also depend on other economic, political and technological factors that cannot be predicted with certainty. Our method of projecting animal populations assumed only one of many possible patterns of future population change.

The four sources we found in the literature for animal-waste emission factors are listed in Table 4. It was challenging to develop a single emission factor to apply to large populations of animal (e.g. "Beef and Buffalo", "Pigs", Table 4) because actual emissions depend on the $\mathrm{N}$ content in and composition of feed; the age, weight, and type (e.g. beef cow vs dairy cow) of animal; the manner in which the animals are housed and the manure handled; and so forth (Battye et al., 1994). One approach to constructing $\mathrm{NH}_{3}$ emissions inventories is to collect data on an animal population by specific subcategory of animal and then to obtain an emissions factor developed for that specific subcategory. Furthermore, since animal husbandry and animal population structures change from region to region and with time, emission factors should only be used with the particular year for which they are developed. We selected emission factors from the 
Table 4. Animal emission factors, $\mathrm{kg} \mathrm{N}$ animal $^{-1} \mathrm{yr}^{-1}$

\begin{tabular}{lccccl}
\hline $\begin{array}{l}\text { Beef and } \\
\text { buffalo }\end{array}$ & P.gs & $\begin{array}{c}\text { Sheep and } \\
\text { goats }\end{array}$ & $\begin{array}{c}\text { Horses } \\
\text { and mules }\end{array}$ & Poultry & Reference \\
\hline 10.0 & 12.0 & 4.4 & 10.0 & 0.20 & Dentener and Crutzen, 1994 \\
15.5 & 2.35 & 2.4 & 15.0 & 0.21 & Schlesinger and Hartley, 1992 \\
10.5 & 4.1 & 1.8 & 10.3 & 0.26 & Zhao and Wang, 1994 \\
18.9 & 7.58 & 2.78 & 10.0 & 0.3117 & Battye et al., 1994 \\
& & & & 0.1375 & \\
\hline
\end{tabular}

\footnotetext{
${ }^{a}$ Battye et al. (1994) developed composite emission factors for various livestock categories based on 1991 population compositions. In applying these emission factors to the historical and projected United States animal population record, we assumed that livestock population compositions remained generally the same through time. Our emission factor for "beef and buffalo" is the EPA composite emission factor for cattle and calves; for "pigs", it is the composite for hogs and pigs; for "sheep and goats", it is the composite for sheep and lambs. The value for "horses and mules" is for horses only. We have calculated an emission factor for chickens $(0.3117)$ exclusive of broiler chickens based on population and emission-factor data in Battye et al. (1994). The emission factor of 0.1375 was applied to broiler chickens.
}

current literature that are appropriate for animal populations of the United States and China (Table 4). Application of the same emission factors to the entire historical and projected animal population record introduces error into the results but does not, in our opinion, change the validity of our comparisons regarding overall $\mathrm{N}$ mobilization in the two countries. For the United States, we used the Battye et al. (1994) compilation of composited emission factors (Table 4). For China, we used a range of emission factors because of the differences in animal husbandry. To calculate Chinese minima and maxima animal emission factors, we used the Dentener and Crutzen (1994) values, reduced by $40 \%$ to account for the dispersive nature of animal husbandry practices in less-developed countries (Dentener and Crutzen, 1994), together with the Schlesinger and Hartley (1992) and the Zhac and Wang (1994) values (Table 4). We did not consider Battye et al. (1994) because their values are based specifically on the 1991 animal population structures of animals in the United States (Table 4).

\section{RESULTS AND DISCUSSION}

\section{$N_{\mathrm{R}}$ creation and emissions by fossil-fuel combustion}

In $1950 \mathrm{~N}_{R}$ creation by fossil-fuel combustion in the United States was about $3 \mathrm{Tg} \mathrm{N} \mathrm{yr}^{-1}$. By the mid1970s, this figure had doubled but then remained approximately constant to 1990 (Fig. 1). NO $_{x}$ emissions in the United States seem to have flattened primarily because of (1) decreased energy consumption stemming both from increased energy efficiency and from structural changes in the United States economy (OTA, 1990) and (2) federal motor-vehicle emission standards. EPA (1994) predicts that $\mathrm{NO}_{x}$ emissions will decline somewhat before 2000 and will rise again through 2010 . We assumed this latter trend would continue until 2020 (that is, that emissions would rise slightly). The resulting projections indicate that $2020 \mathrm{NO}_{x}$ emissions would approximately equal

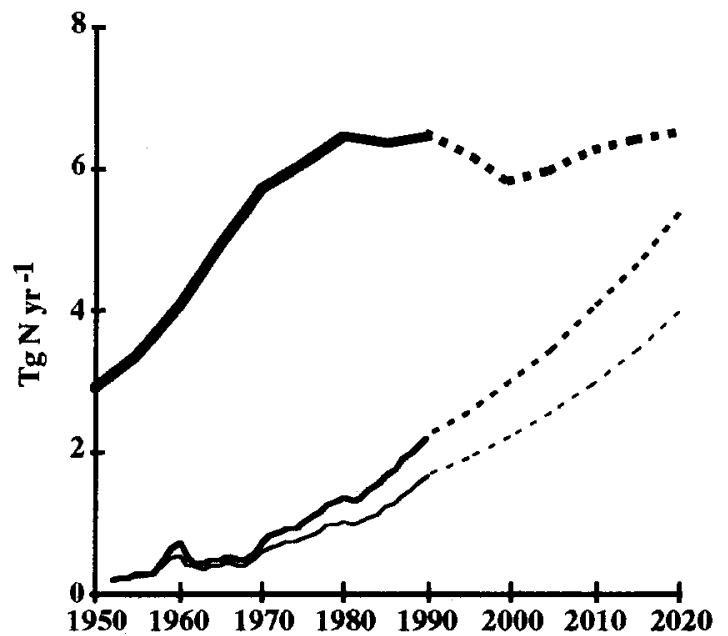

Fig. 1. Atmospheric emission rates of $\mathrm{NO}\left(\mathrm{Tg} \mathrm{Nyr}^{-1}\right)$ from fossil-fuel combustion from 1950-1990 (solid lines) and our projections for 1990-2020 (dashed lines) in China (narrow line, minimum; medium line, maximum) and the United States (heavy line).

1990 levels (Fig. 1). The historical pattern for China is quite different. In the $1950 \mathrm{~S} \mathrm{~N}_{\mathrm{R}}$ creation (i.e. $\mathrm{NO}_{x}$ emissions) was relatively low, about $0.2 \mathrm{Tg} \mathrm{Nyr}^{-1}$, and did not increase substantially until the 1970 s, just as the United States creation rate was leveling out. By 1989 , the range was $1.6-2.2 \mathrm{Tg} \mathrm{N} \mathrm{yr}^{-1}$. Future projections showed steady increases in $\mathrm{NO}_{x}$ emissions in China; we estimated that by 2020 the range would be about 3.9-5.4 $\mathrm{Tg} \mathrm{N} \mathrm{yr}^{-1}$ (Fig. 1).

Other estimates for $\mathrm{NO}_{x}$ emissions in China were higher. For example, for 1986 we estimated that $1.2-1.7$ $\mathrm{Tg} \mathrm{N} \mathrm{yr}^{-1}$ were emitted, less than the $2.1 \mathrm{Tg} \mathrm{N} \mathrm{yr}^{-1}$, $2.3 \mathrm{Tg} \mathrm{N} \mathrm{yr}^{-1}$, and $2.9 \mathrm{Tg} \mathrm{Nyr}^{-1}$ estimated by Kato and Akimoto (1992), Foell and Green (1990), and Hao et al. (1994), respectively. The emission factors we used for coal combustion in industrial boilers $(0.47-2.2 \mathrm{~kg}$ $\mathrm{N} \mathrm{tce}{ }^{-1}$; Table 1) and for electricity generation from coal combustion (1.75 kg N tce ${ }^{-1}$; Table 1) were lower 
than values used in other studies. For example, in an analysis of $\mathrm{NO}_{x}$ emissions in Asia, Kato and Akimoto (1992) use emission factors of $7.50 \mathrm{~kg} \mathrm{NO}_{2}$ ton $^{-1}$ (3.2 $\mathrm{kg} \mathrm{N}$ tce $^{-1}$ ) and $9.95 \mathrm{~kg} \mathrm{NO}_{2}$ ton $^{-1}\left(4.2 \mathrm{~kg} \mathrm{~N}\right.$ tce $\left.^{-1}\right)$ for coal use in industrial boilers and power generation, respectively. These values are from more highly developed industrial regions. The emission factors used in this paper were determined specifically for China (Table 1) and have accounted for the lowercombustion temperatures and less-efficient combustion practices in China as compared to those in more developed regions (e.g. see Smil, 1993). Although the amount of fossil fuel used in China is well known, the magnitude of $\mathrm{NO}_{x}$ emissions to the atmosphere from combustion is not. There is little uncertainty, however, about the conclusion that $\mathrm{NO}_{x}$ emissions will increase in the future given China's population growth and industrialization patterns.

\section{$N_{\mathrm{R}}$ creation from fertilizer application}

Commercial nitrogenous fertilizer use in China and the United States can be divided into three periods: (1) Before 1965: little use in either country; (2) mid1960 to mid-1970: rapidly increased use in both countries; (3) mid-1970 to 1990: stabilized use ( $\approx 10 \mathrm{Tg}$ $\left.\mathrm{N} \mathrm{yr}^{-1}\right)$ in the United States but continued increase $\left(\approx 8 \% \mathrm{yr}^{-1}\right.$ ) in China. By $1990 \approx 20 \mathrm{TgN} \mathrm{yr}^{-1}$ were being used in China (Fig. 2).

Our results for China were generally consistent with other estimates of applied $\mathrm{N}$ fertilizer. Zhu (1992) reports that $0.06,8.40,11.92$, and $13.96 \mathrm{Tg} \mathrm{Nyr}^{-1}$ of chemical fertilizer were used in 1952,1979, 1983 and 1987, respectively. Han and Xie (1993b) estimate that $0.08,0.32,1.33,2.50,3.31,10.09,13.12$, and $14.97 \mathrm{Tg}$ $\mathbf{N ~ y r}^{-1}$ of chemical fertilizer were applied to Chinese fields in 1952, 1957, 1965, 1970, 1975, 1980, 1984, and 1988, respectively. Matthews (1994) gives a value of 15.1 Tg N for fertilizer use in China for 1984/1985. Zhang et al. (1994) estimate that $13.5 \mathrm{Tg} \mathrm{N} \mathrm{yr}^{-1}$ were applied in 1990. Lastly, Zhao and Wang (1994) estimate that $65.4 \mathrm{Tg} \mathrm{N}$ were applied as fertilizer in 1990 . Except for the latter estimate (Zhao and Wang report the amount of $\mathrm{N}$-containing fertilizer instead of $\mathrm{N}$ fertilizer as $\mathrm{N}$ ), these others are 5-20\% lower (depending on source and year) than those reported in the United Nations documents. The annual patterns of $\mathrm{N}$ fertilizer use of Zhu (1992) and Han and Xie (1993b) are consistent with our estimates of the rate of increase.

Our 2020 projections (which extrapolate Constant and Sheldrick's 1992 projections) assume little growth in the United States (about $0.2 \% \mathrm{yr}^{-1}$ ) and steady growth in China $\left(2.73 \% \mathrm{yr}^{-1}\right)$. At such rates, about twice as much fertilizer $\mathrm{N}$ will be applied in China in 2020 than in 1990 . Zhang et al. (1994) estimate that $96 \mathrm{Tg} \mathrm{N} \mathrm{yr}^{-1}$ will be used in 2020 , more than double our estimate. Han and Xie (1993a) and Han (Department of Agronomy, Beijing Agricultural University, personal communication, 1994) predict that future application rates of commercial nitrogenous fertilizer in 2000 and 2025 (based on $\mathrm{N}$-input requirements and

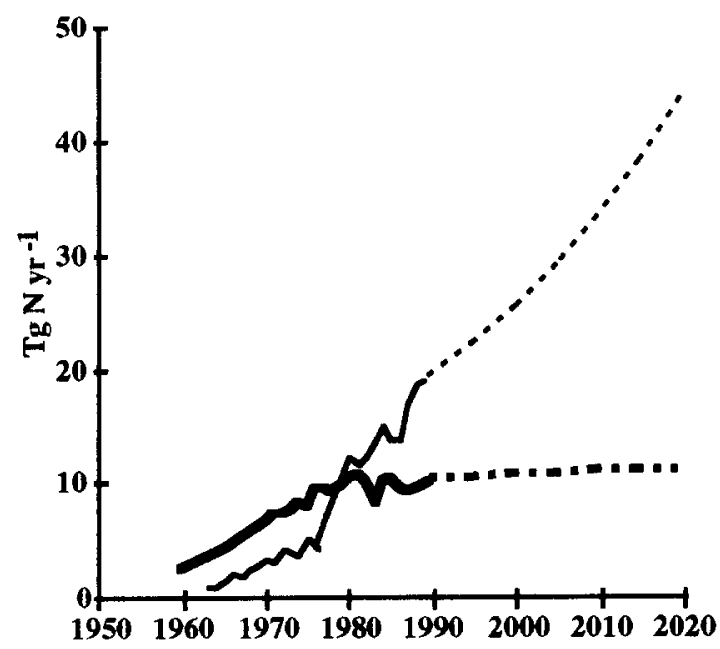

Fig. 2. The amount of commercial nitrogenous fertilizer applied from 1950 to 1990 (solid lines) and our projections for 1990-2020 (dashed lines) in China (narrow line) and the United States (heavy line).

assuming that diet and production efficiency will be unchanged) will be 31.3 and $36.2 \mathrm{Tg} \mathrm{N}$, respectively, of chemical $\mathrm{N}$ in fertilizer. Their estimate for 2000 is larger than ours $\left(\approx 25 \mathrm{Tg} \mathrm{Nyr}^{-1}\right)$ and their 2025 estimate is about $10 \%$ lower than our 2020 estimate $\left(\approx 40 \mathrm{Tg} \mathrm{N} \mathrm{yr}^{-1}\right.$ ). Although projections vary, the direction of change is clear-use of nitrogenous fertilizers in China will continue to increase. The actual rate of increase will depend on production levels, import policies, fertilizer costs relative to returns from crop production, and agricultural practices.

\section{$N_{\mathbf{R}}$ creation by legume and rice cultivation}

Our results indicated that in 1980 and 1990 the $\mathrm{N}_{\mathrm{R}}$ from cultivation ranged from about 2 to about $4 \mathrm{Tg} \mathrm{Nyr}^{-1}$ for both China and the United States (Table 2). Given the lack of variation over this 10-year period, we assumed that the rate in 2020 would be similar to the current rate.

Because we had no equivalent data on area under leguminous forage cultivation (e.g. vetch, alfalfa, clover), we could not include $\mathrm{N}$ fixation by forage crops. For China, the missing information did not seriously impact the total $\mathrm{N}$ fixed by cultivation because only about $10 \%$ is from forages ( $\mathrm{Zhu}, 1992)$. For the United States, in 1987 about $9.95 \times 10^{6}$ ha were cultivated to grow alfalfa (Bureau of Census, 1993). At an $\mathrm{N}$ fixation rate of $36 \mathrm{~kg} \mathrm{~N}^{-1}$ (Zhu, 1992) (see below), this equals about $0.34 \mathrm{Tg} \mathrm{N} \mathrm{yr}^{-1}$ or about $10 \%$ of that fixed in 1990 . Since we did not know the area cultivated with vetch and clover, we probably underestimated $\mathrm{N}$ fixation by forage cultivation in the United States.

There were other sources of uncertainty in our calculations. A major one was the selection of a fixation rate. Our $\mathrm{N}$ fixation rate of $70-140 \mathrm{~kg} \mathrm{Nha}^{-1}$ may be too large. In an excellent review, Zhu (1992) 
finds that the ranges of fixation rates for soybeans, peanuts, pulses, and forages are 3-102, 82-106, 20-34 and $20-52 \mathrm{~kg} \mathrm{Nha}^{-1}$, respectively, with means of 51 , 96,28 , and about $36 \mathrm{~kg} \mathrm{~N} \mathrm{ha}^{-1}$. Our forage range was estimated from data in Table 3 of Zhu (1992). In general, Zhu's values for the fixation rates of legumes are significantly lesis than the earlier estimates although his estimate for rice, $45 \mathrm{~kg} \mathrm{~N}^{-1} \mathrm{yr}^{-1}$, is similar to that of Burns and Hardy's (1975), $30 \mathrm{~kg}$ $\mathrm{N}$ ha ${ }^{-1}$. Using his fixation rates and including fixation by forages, Zhu (1992) estimates that the total $\mathrm{N}$ fixations by agriculture were $3.4,3.3,3.3,3.4 \mathrm{Tg}$ $\mathrm{N} \mathrm{yr}^{-1}$ for $1952,1979,1983$ and 1987 , respectively. As it turns out, these values are similar to those we calculated (Table 2) because of the preponderance of rice cultivation in China. In addition to the lack of data about cultivated area for some crops (e.g. forage crops in the United States), N-fixation rates for specific crops vary by factors of 2-3.

In spite of the uncertainties in our fixation rates by legume and rice cultivation, the amount of $\mathrm{N}$ fixed by cultivation seemed to have been relatively constant over the last decade (Table 2) and that contribution to $\mathrm{N}_{\mathrm{R}}$ was small $(\approx 20 \%$ ) relative to fertilizer use and combustion in China and the United States.

$N_{\mathrm{R}}$ emissions from fertilizer use and animal waste

Atmospheric emissions of $\mathrm{NH}_{3}$ from anthropogenic processes come from two major sources-direct emission from fertilized fields and indirect emission from animal waste after fertilizer $\mathrm{N}$ has cycled through crops and animals. Between 1950 and 1990, $\mathbf{N H}_{3}$ emission from these sources increased as fertilizer use and animal populations rose. In the United States in 1990 , these two processes emitted about $0.5 \mathrm{Tg} \mathrm{N} \mathrm{yr}^{-1}$ (Fig. 3(a)) and $2.6 \mathrm{Tg} \mathrm{N} \mathrm{yr}^{-1}$ (Fig. 3(b)), respectively, for a total of $3.1 \mathrm{Tg} \mathrm{Nyr}^{-1}$. In China, the range of $\mathrm{NH}_{3}$ emissions from the two processes was 1.9-3.8 $\mathrm{Tg} \mathrm{N} \mathrm{yr}^{-1}$ (Fig. 3(a)) and 2.3-5.7 $\mathrm{Tg} \mathrm{N} \mathrm{yr}^{-1}$ (Fig. 3(b)), respectively, for a total of $4.2-9.5 \mathrm{Tg}$ $\mathrm{N} \mathrm{yr}^{-1}$ in 1990 . We estimated that the United States emissions in 2020 would be similar to current levels but the total Chinese $\mathrm{NH}_{3}$ emissions would increase to 7.3-16.2 $\mathrm{Tg} \mathrm{N} \mathrm{yr}^{-1}$ depending on the emission factor used (Fig. 3) and the rate of increase in fertilizer use and animal populations.

$\mathrm{N}_{2} \mathrm{O}$ and $\mathrm{NO}$ are clso emitted to the atmosphere as a consequence of fertilizer use and subsequent soil nitrification and denitrification. Their formation and emission rates are influenced by several factors including soil type, soil moisture and oxygen content, $\mathrm{pH}$, organic carbon, and agricultural practices.

Matthews (1994) reviews $\mathrm{N}_{2} \mathrm{O}$ emission factors associated with different types of fertilizer application. For the six fertilizer types used in the United States, we used the median emission factors from her Table 4 (for $\left(\mathrm{NH}_{4}\right)_{2} \mathrm{SO}_{4}, 0.12 \%$; for anhydrous $\mathrm{NH}_{3}, 0.11 \%$; for aqua $\mathrm{NH}_{3}, 0.11 \%$; for $\mathrm{N}$ solutions, $0.11 \%$; for $\mathrm{NaNO}_{3}, 0.05 \%$; for $\mathrm{NH}_{4} \mathrm{NO}_{3}, 0.26 \%$; and for urea, $0.11 \%$ ). In China we used the median emission factor
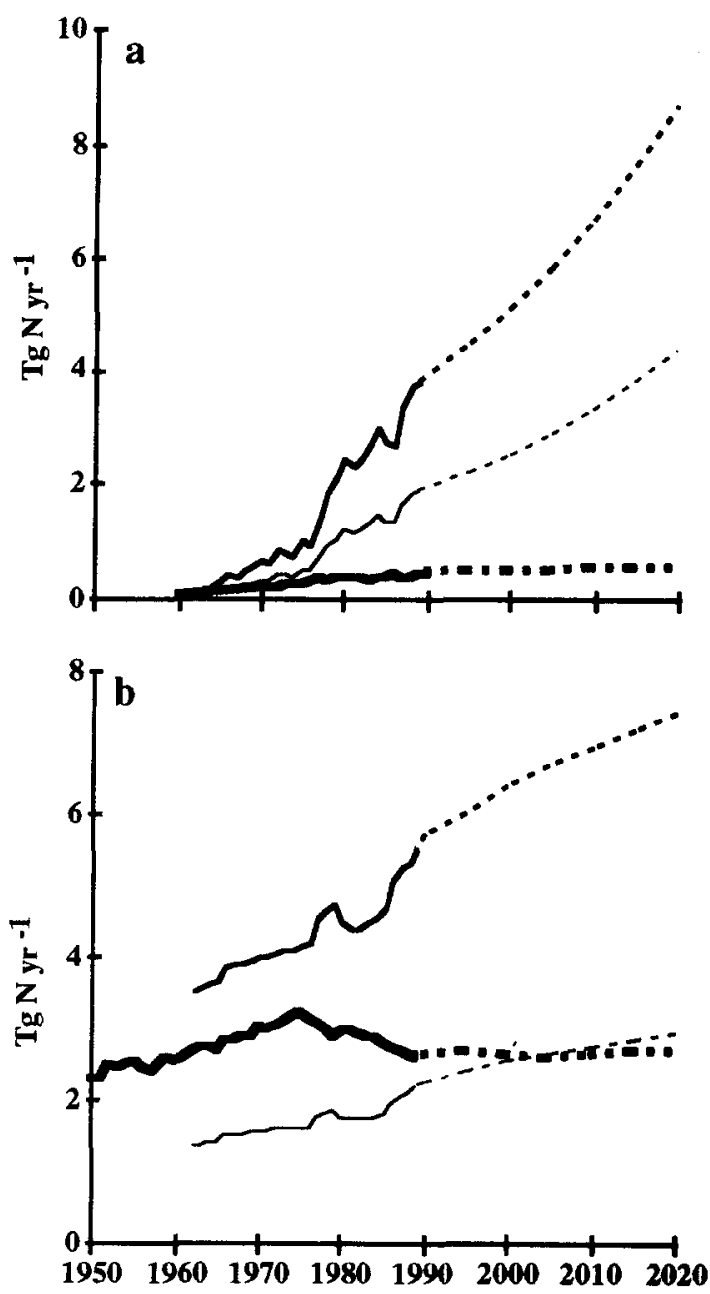

Fig. 3. Atmospheric emission rates of $\mathrm{NH}_{3}\left(\mathrm{Tg} \mathrm{N} \mathrm{yr}^{-1}\right)$ from (a) fertilizer and (b) domestic animal waste to 1990 (solid lines) and our projections for 1990-2020 (dashed lines) in China (narrow line, minimum; medium line, maximum) and the United States (heavy line).

of $0.11 \%$ for urea and other nitrogenous fertilizers (Matthews, 1994) in a mix of $30 \%$ and $70 \%$, respectively. The resulting emissions were about 0.02 and $0.01 \mathrm{Tg} \mathrm{N} \mathrm{yr}^{-1}$ for China and the United States, respectively. Currently, global $\mathrm{N}_{2} \mathrm{O}$ emissions from fertilizer use are about $0.1 \mathrm{Tg} \mathrm{N} \mathrm{yr}^{-1}$ (Matthews, 1994); China accounts for about $20 \%$ of this value. Chinese $\mathrm{N}_{2} \mathrm{O}$ emissions will most likely increase with increased fertilizer use. As these emissions increase and those in more developed regions stay constant, China will contribute a greater portion of $\mathrm{N}_{2} \mathrm{O}$ to the global atmosphere. As already mentioned, $\mathrm{N}_{2} \mathrm{O}$ emissions do not account for much of the $\mathrm{N}_{\mathrm{R}}$ created by fertilizer application. However $\mathrm{N}_{2} \mathrm{O}$ is a greenhouse gas and influences stratospheric $\mathrm{O}_{3}$.

Yienger and Levy (1994) estimate that currently about $0.2 \mathrm{Tg} \mathrm{yr}^{-1}$ of NO are emitted from fertilizer applied in China and Japan together based on a total fertilizer use of $19.4 \mathrm{Tg} \mathrm{N} \mathrm{yr}^{-1}$. From these values, we 
a

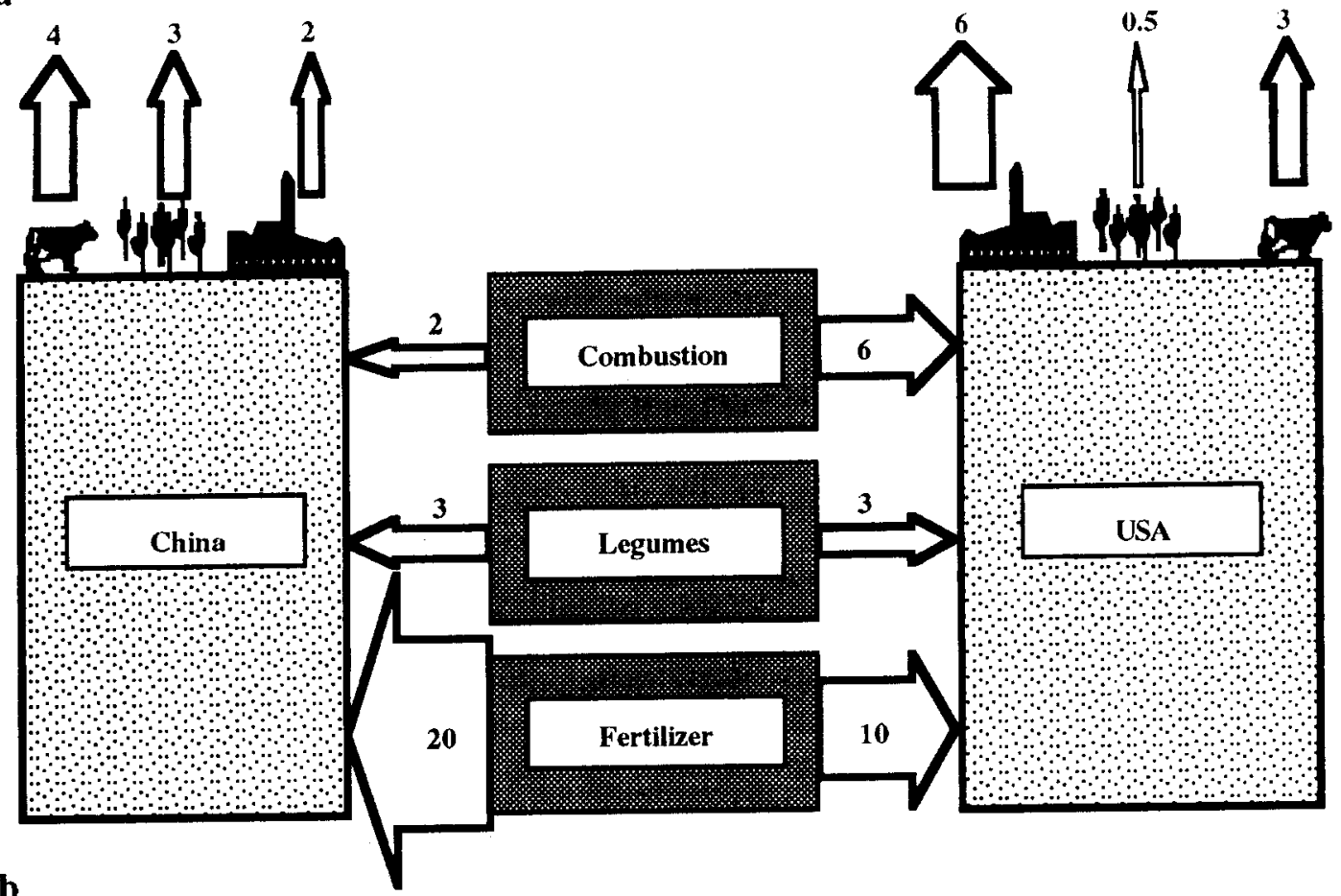

b
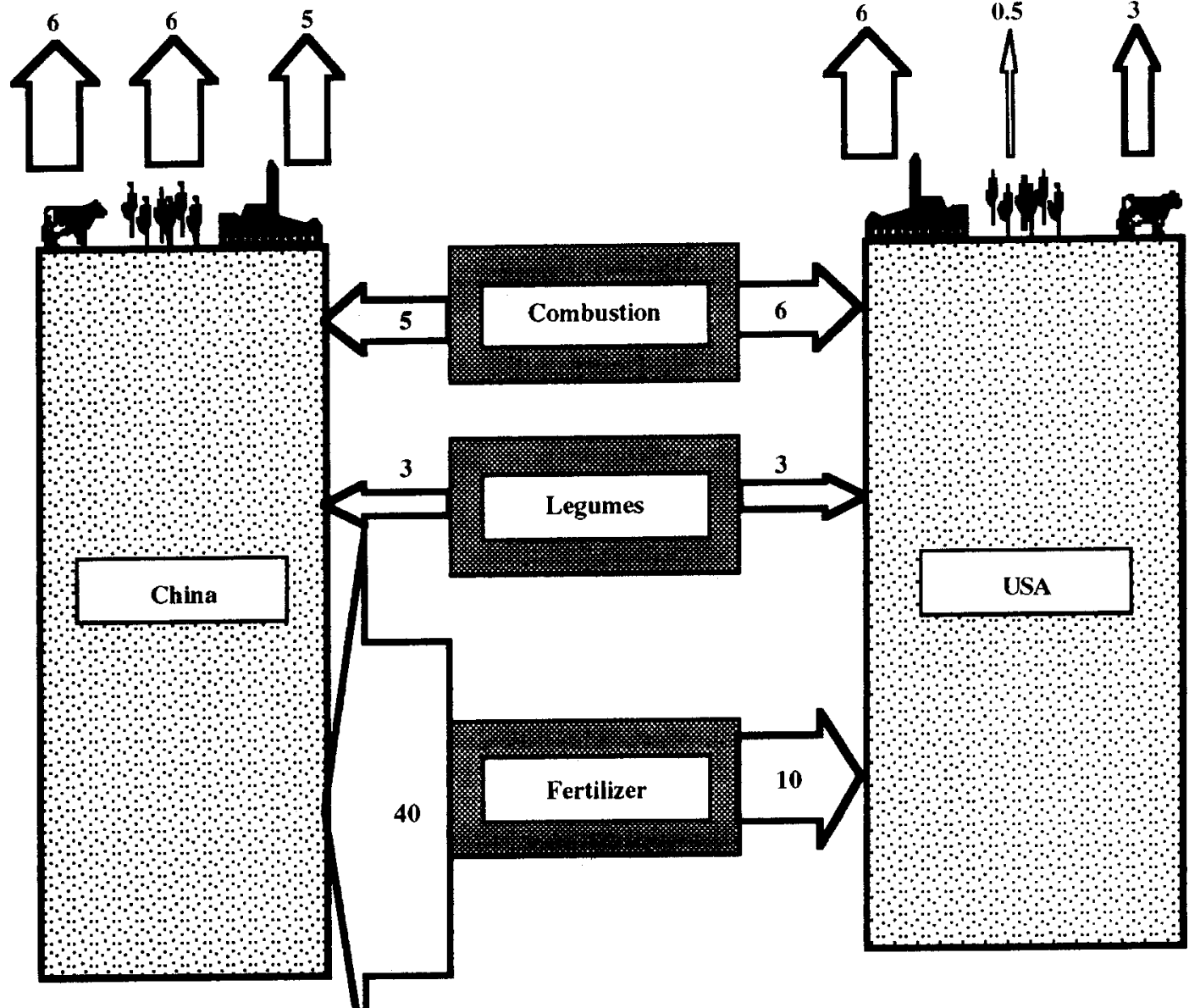

40

Fertilizer

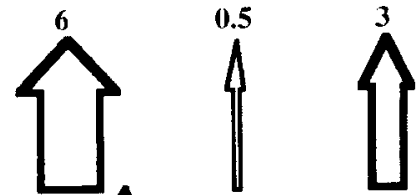

3
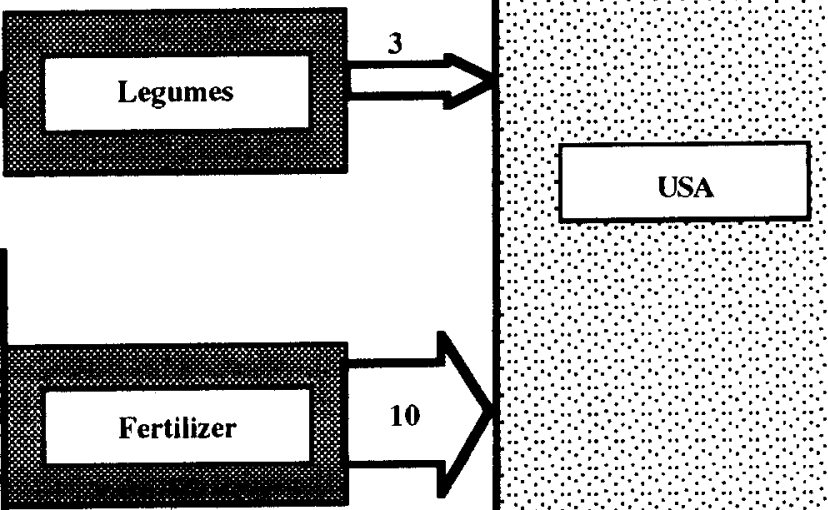

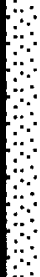

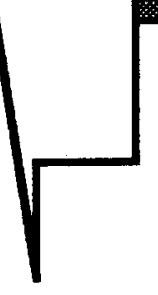

Fig. 4. $\mathrm{N}$ mobilization and atmospheric emission rates $\left(\mathrm{Tg} \mathrm{N} \mathrm{yr}^{-1}\right)$ in China and the United States for (a) 1990 and (b) 2020. The arrows over the factories represent $\mathrm{NO}_{x}$ emissions from combustion; those over the vegetation represent $\mathrm{NH}_{3}$ from applied fertilizer; and those over the animal represent $\mathrm{NH}_{3}$ from animal waste. 
estimated that in 1989-when China used $18.9 \mathrm{Tg}$ $\mathrm{N} \mathrm{yr}^{-1}$ of commercial fertilizer-emissions of $\mathrm{NO}$ were about $0.2 \mathrm{Tg} \mathrm{N} \mathrm{yr}^{-1}$. This rate is about a factor of ten less than that from fossil-fuel combustion in China (Fig. 1). Assurning NO emissions from fertilizer use increase at the rate that applied fertilizer does, 2020 emissions would be about $0.4 \mathrm{Tg} \mathrm{N} \mathrm{yr}^{-1}$. These current and future NO emissions could significantly influence $\mathrm{O}_{3}$ formation in China and might have a negative impact on crop production (Chameides $e t$ al., 1994). Yienger and Levy (1994) estimate that North America (United States and Canada) emits about $0.21 \mathrm{Tg} \mathrm{N} \mathrm{yr}^{-1}$ of $\mathrm{NO}$ from fertilizer-induced emissions. Assuming that $>90 \%$ of this is emitted in the United States because of its large population and warmer temperatures, biogenic NO emissions from agricultural practices are small relative to fossil-fuel emissions in the United States (Fig. 1).

\section{SUMMARY}

From 1960 to $1990, \mathrm{~N}$ mobilized by fertilizer production and fossil-fuel combustion in the United States decreased from $\approx 25 \%$ of the global total to $\approx 15 \%$. In 2020 , we have projected that the United States contribution to the global total will further decrease to $\approx 10 \%$. Conversely, we have projected that China's contribution to the global total will increase from $\approx 20 \%$ in 1990 to $\approx 25 \%$ in 2020 .

In China, most reactive $\mathrm{N}$ appears to be created through agricultural practices. In $1990, \approx 25 \mathrm{Tg}$ of $\mathrm{N}_{\mathrm{R}}$ were created and $\approx 80 \%$ of that came from fertilizer use with the remainder from combustion and cultivation (Fig. 4). In the United States, $\approx 20 \mathrm{Tg}$ of $N_{R}$ were created in 1990 but the mix was different. Fertilizer use accounted for about $50 \%$; combustion and cultivation made up the remainder. If the rapid increase in Chinese fertilizer use continues, as our projections assumed, $\mathrm{N}_{\mathrm{R}}$ creation will rise to about $40 \mathrm{Tg} \mathrm{N} \mathrm{yr}^{-1}$ by 2020 (Fig. 4). By contrast, if fertilizer application rates in the United States follow recent trends, there will be little change by 2020 . Over the last few decades, the emissions of $\mathrm{N}_{\mathrm{R}}$ to the atmosphere have been dominated by $\mathrm{NO}_{x}$ in the United States and by $\mathrm{NH}_{3}$ in China. Our projections show little change in this pattern (Fig. 4). Although our estimates have predicted a growing disparity in how much nitrogen is mobilized in the United States vs. China, the differences are not as striking as they could be given that the projected 2020 populations for these two countries are 0.29 billion for the United States and 1.49 billion for China (Urban and Trueblood, 1990).

To account for the uncertainties in emission factors, we have provided minimum and maximum values (e.g. Fig. 3). Although the $\mathrm{NO}_{x}$ emission factors for China's industrial boilers we used here are lower than factors used by others, our estimates seem consistent with the documentec inefficiency and low combustion temperatures of Chinese boilers (Smil, 1993), conditions that would be associated with less $\mathrm{NO}_{x}$ emitted per unit of fuel burned. Further emissions testing would certainly help resolve some of the uncertainties.

We believe our projections realistically portray the potential magnitude and probable direction of what will probably happen in these two countries if current practices continue. $\mathbf{N}$ mobilization and atmospheric emission (and deposition) in the United States will probably not change much over the next few decades but fertilizer use and fossil-fuel combustion in China will probably increase significantly over the same period, resulting in substantial increases in the availability of $N_{R}$ within, downwind, and downstream of China.

We have not discussed the potential policy issues raised by these estimates; rather, we enlarge on them in Thomson and Galloway (1994). In that paper we consider what these data imply for each country's respective development path, we compare historical and projected emissions with expectations generated from development theory, and we examine our $\mathrm{N}$ emissions data on a per capita basis. For example, when considering the implications of the data presented here, one cannot forget that per capita contributions to $N_{R}$ formation and emissions-even in 2020 -in the U.S. will still far exceed those in China.

In closing, human interference in the $\mathrm{N}$ cycle is extensive and complex. Human-induced releases of $N_{R}$ are not only regional but also global. Once $N_{R}$ is created, it is transformed by microbial and atmospheric processes into a variety of $\mathrm{N}$ species, each of which has unique transport characteristics and ecosystem impacts. This paper has addressed only $\mathrm{N}_{\mathrm{R}}$ formation and atmospheric emissions. For a more thorough understanding of the fate and effects of $\mathrm{N}_{\mathrm{R}}$ on the United States and China, not only do the uncertainties about $N_{R}$ creation rates need to be resolved (especially in China) but also the distribution of $\mathbf{N}_{R}$ by hydrologic and atmospheric transport should be addressed before the ultimate fate of $N_{R}$, its rate of accumulation, and its impacts on biogeochemical processes can be determined.

Acknowledgements-We gratefully acknowledge Matt Weber's assistance in gathering much of the data used in this analysis. We also thank James Harding, Janice Berry (Tennessee Valley Authority, National Fertilizer and Environmental Research Center), and David Terry (University of Kentucky) for compiling the United States fertilizer data. The comments of Greg Carmichael, Hunter Colby, Han Chun Ru, Robert Howarth, Li Changsheng, William Moomaw, David Schimel, Vaclav Smil, and Zhu Zhao-liang are sincerely appreciated. James Galloway is grateful to The Ecosystems Center of the Marine Biological Station, the Woods Hole Oceanographic Institute, and the International Institute for Applied Systems Analysis for hosting him during his sabbatical year. We appreciate the assistance of Mary-Scott Kaiser, who did her usual great job of editing, and Kathy Garstang, who assisted with the graphics. Research partially supported by National Science Foundation Award \# ATM-9414293. 


\section{REFERENCES}

Aber J. D., Nadelhoffer K. J., Steudler P. and Melillo J. M. (1989) Nitrogen saturation in northern forest ecosystems. BioScience 39, 378-386.

Arndt R. and Carmichael G. R. (1995) Regional impacts of the expanding energy use in Asia. In Proc. 6th Global Change Studies Symp., Dallas, TX, 15-20 January 1995.

Ayres R. U., Schlesinger W. H. and Socolow R. H. (1994) Human impacts on the carbon and nitrogen cycles. In Industrial Ecology and Global Change (edited by Socolow R., Andrews C., Berkhout R. and Thomas V.), pp. 121-155. Cambridge University Press, England.

Battye R., Battye W., Overcash C. and Fudge S. (1994) Development and selection of ammonia emission factors. EPA Report No. EPA/600/R-94/190, Office of Research and Development, U.S. Environmental Protection Agency, Washington, D.C.

Bureau of Census (1993) 1987 Census of Agriculture Vol. 1: Geographic Area Series. (CD-ROM) Data User Services Division, United States Department of Commerce, Washington, D.C.

Burns R. C. and Hardy R. W. F. (1975) Nitrogen Fixation in Bacteria and Higher Plants. Springer, New York.

Chameides W. L., Kasibhatla P. S., Yienger J. and Levy II H. (1994) Growth of continental-scale metro-agro-plexes, regional ozone pollution and world food production. Science 264, 74-77.

Chinese State Planning Commission (Institute of Energy Research and Institute of System Analysis of Economy and Energy) (1993) Environmental Problems in Energy Development Project in China. China Press of Construction Materials, Beijing (in Chinese).

Constant K. M. and Sheldrick W. F. (1992) World Nitrogen Survey, World Bank Technical Paper Number 174. Asia Technical Department Series, The World Bank, Washington, D.C.

Dentener F. J. and Crutzen P. J. (1994) A three-dimensional model of the global ammonia cycle. J. atmos. Chem. 19, 331-369.

EPA (United States Environmental Protection Agency) (1994) National air pollutant emission trends, 1900-1993. EPA-454/R-94-027, Technical Support Division, Research Triangle Park, NC.

FAO (Food and Agricultural Organization) (1958, 1963, $1968,1971,1973,1976,1979,1982,1988,1990,1992,1993)$ FAO Yearbook: Production, FAO Statistics Series, Statistical Analysis Service, Statistics Division, FAO, Rome.

Foell W. K. and Green C. W. (1990) Acid rain in Asia: an economic, energy and emissions overview. In Proc. 2nd Annual Workshop Acid Rain in Asia, 19-22 November, Asian Institute of Technology, Bangkok.

Galloway J. N. and Likens G. E. (1981) Acid precipitation: The importance of nitric acid. Atmospheric Environment 15, 1081-1085.

Galloway J. N., Levy II H. and Kasibhatla P. S. (1994) Year 2020: Consequences of population growth and development on deposition of oxidized nitrogen. Ambio 23, 120-123.

Galloway J. N., Schlesinger W. H., Levy II H., Michaels A. and Schnoor J. L. (1995) Nitrogen fixation: anthropogenic enhancement-environmental response. Global Biogeochem. Cycles 9, 235-252.

Han C. and Xie Z. (1993a) Macroscopic features of nitrogen transformation and cycling in the agroecosystem in China and its implications to ecological agriculture. Eco-Agriculture Res. 1, 58-68 (in Chinese).

Han C. and Xie Z. (1993b) Managing $N$ input and cycling towards agricultural sustainability-a study on general features of $\mathbf{N}$ cycle in Chinese agroecosystems. Paper presented at Sustainable Development Symp., Beijing, 10-13 September 1993.

Hao J., Xi D., Lu Y., Zhou Z. and He K. (1994) Estimation of greenhouse gas emissions and sinks in China, 1990. Subre- port No. 1, China: Issues and Options in Greenhouse Gas Emissions Control. The World Bank, Industry and Energy Division, China and Mongolia Department, East Asian and Pacific Regional Office, Washington D.C.

Heck W. W., Heagle A. S. and Shriner D. S. (1986) Effects on vegetation: Native, Crops, Forest. In Air Pollution (edited by Stern A. S.), Vol. 6., pp. 247-350. Academic Press, New York.

IEA (International Energy Agency) (1992) World Energy Statistics and Balances. Organization for Economic Cooperation and Development, Paris.

Kato N. and Akimoto H. (1992) Anthropogenic emission of $\mathrm{SO}_{2}$ and $\mathrm{NO}_{x}$ in Asia: Emission inventories. Atmospheric Environment 26A, 2997-3017.

Keyser H. H. and Li F. (1992) Potential for increasing biological nitrogen fixation in soybeans. Plant and Soil 141, $119-135$.

LaRue T. A. and Patterson T. G. (1981) How much nitrogen do legumes fix? Adv. Agronomy 34, 15-38.

Matthews E. (1994) Nitrogenous fertilizers: Global distribution of consumption and associated emissions of nitrous oxide and ammonia. Global Biogeochem. Cycles 8 , 411-439.

Nixon S. W. (1995) Coastal marine eutrophication: A definition, social causes, and future concerns. Ophelia 41, 199-219.

OTA (Office of Technology Assessment) (1990) Energy Use and the U.S. Economy. U.S. Congress, Government Printing Office, Washington, D.C.

Pacyna J. M., Larssen S. and Semb A. (1991) European survey for $\mathrm{NO}_{x}$ emissions with emphasis on Eastern Europe. Atmospheric Environment 25A, 425-439.

Schlesinger W. H. and Hartley A. E. (1992) A global budget for atmospheric $\mathrm{NH}_{3}$. Biogeochemistry 15, 191-211.

Semb A. and Amble E. (1981) Emission of nitrogen oxides from fossil fuel combustion in Europe. Teknisk Rapport Nr. 13/81 (00578), Norwegian Institute for Air Research, Lillestrom, Norway.

Sinton J. E., Levine M. D., Liu F., Davis W. B., Jiang Z., Zhuang X., Jiang K. and Zhou D. (eds.) (1993) China Energy Databook. (1992 Edition, revised June 1993) LBL32822. Rev.2, UC-350, National Technical Information Service, Springfield, VA.

Smil V. (1993) China's Environmental Crisis. M. E. Sharpe, Armonk, NY.

Smil V. (1995) Concepts and Methods: Who will feed China? China Quart. 143, 105-117.

Thomson V. E. and Galloway J. N. (1994) Sustainable development and nitrogen air pollution in the United States and the People's Republic of China. Paper presented at the Association for Public Policy Analysis and Management Annual Meeting, Chicago, Illinois, October.

UN (United Nations) (1971, 1972, 1973, 1974, 1975, 1977 , $1978,1979-1980,1981,1982,1983-1984,1985-1986$, 1987, 1988-1989) Statistical Yearbook. United Nations, New York.

Urban F. and Trueblood M. (1990) World population by country and region, 1950-2020. Staff Report No. AGES 9024, United States Department of Agriculture, United States Government Printing Office, Washington, D.C.

USDA (United States Department of Agriculture) (1951-1992) Agricultural Statistics. United States Government Printing Office, Washington, D.C.

USDA (United States Department of Agriculture) (1995) Long-term agricultural baseline projections, 1995-2005. Staff Report No. WAOB-95-1, United States Government Printing Office, Washington, D.C

Wang N.-C. (1974) Essentials of Chemical Fertilizer Use in $P R C$. Fuel and Chemical Industry Publishing Service, Beijing (in Chinese).

Yienger J. J. and Levy II H. (1994) Global inventory of soil-biogenic $\mathrm{NO}_{x}$ emissions. $J$. geophys. Res. 100 , 11,447-11,464. 
Zhang Y., Wells G. J., Duan W., Zhang H., Zhou Y., Sheng Y., Duan Z., Zhang, D. and Bo L. (1994) Greenhouse gas control in the agricultural sector, sub-Report Number 7, In China: Issues and Options in Greenhouse Gas Emissions Control, The World Bank, Industry and Energy Division, China and Mongolia Department, East Asian and Pacific Regional Office, Washington, D.C.
Zhao D. and Wang A. (1994) Estimation of anthropogenic ammonia emissions in Asia. Atmospheric Environment 28, 689-694.

Zhu Z.-L. (1992) Nitrogen balance and cycling in agro-ecosystems of China. In Nitrogen in Soils of China (edited by Zhu Z.-L. and Wen Q. X.). Jiangsu Science and Technology Publishing House, Nanjing (in Chinese). 